\title{
Behavioral mechanism for an associational refuge for macroalgae on temperate reefs
}

\author{
Stuart Levenbach* \\ Department of Ecology, Evolution, and Marine Biology, University of California, Santa Barbara, California 93106, USA
}

Present address: Office of Management and Budget, New Executive Office Bldg., 725 17th Street NW, Room 9215 Washington, DC 20503, USA

\begin{abstract}
Temperate reefs are sensitive to fluctuations in grazing intensity and, while some species of marine algae possess chemical and structural defenses, many species lack adaptations to withstand high grazer densities. The presence of foliose macroalgae in the face of high grazing pressure can have important consequences for higher trophic levels, in part because macroalgae harbor prey for fish and macroinvertebrates. The present study explores a biotic interaction between the sea urchins Strongylocentrotus purpuratus and S. franciscanus and the colonial anemone Corynactis californica, and describes the behavioral underpinnings of an associational refuge for benthic macroalgae on heavily grazed rocky reefs. Field surveys of heavily grazed reefs revealed that macroalgae is more abundant within $C$. californica colonies, and that sea urchins touch far fewer C. californica polyps than would be expected by chance. In laboratory studies, the movement of urchins was impeded when urchins withdrew their tube feet upon contact with $C$. californica. This was probably the behavioral mechanism explaining results of field experiments where recruitment of macroalgae was relatively high among $C$. californica colonies transplanted within a sea urchin barren. C. californica may play an underappreciated role on temperate rocky reefs by altering the behavior of a dominant herbivore and thus providing an associational refuge for important biogenic structure.
\end{abstract}

KEY WORDS: Facilitation · Associational defense $\cdot$ Sea urchin $\cdot$ Corynactis californica $\cdot$ Macroalgae Tube feet

Resale or republication not permitted without written consent of the publisher

\section{INTRODUCTION}

Herbivory is a dominant force affecting the distribution and abundance of terrestrial and marine plants, and many species possess chemical and structural traits that deter herbivores (Rosenthal \& Kotanen 1994, McClintock \& Baker 2001). For species lacking these adaptations, studies of positive interactions have shed light on the importance of associational defenses, whereby one species gains protection when in close proximity to another facilitator species (Stachowicz 2001). Facilitators have been shown to reduce herbivory on vulnerable neighbors in a variety of ways, such as concealing target species from detection (Atsatt \& O'Dowd 1976, Hamback et al. 2000), impeding access (Kerr \& Paul 1995, Rebollo et al. 2002, Gagnon et al.
2003), and deterring herbivores with noxious chemicals (Callaway et al. 2000, Paul et al. 2001) or stinging tentacles (Littler et al. 1987).

The most recent research on associational plant defenses has focused on heavily grazed terrestrial plant communities (Milchunas \& Noy-Meir 2002, Rebollo et al. 2002, Baraza et al. 2006), yet some of the earliest examples came from marine ecosystems (Hay 1986, Pfister \& Hay 1988). In marine ecosystems, temperate reefs are frequently denuded of canopy forming kelp and understory macroalgae by sea urchins (Lawrence 1975, Harrold \& Reed 1985, Watanabe \& Harrold 1991), with extant foliose macroalgae confined to ledges and other physical refuges that are inaccessible to dominant grazers. Associational defenses that enable benthic macroalgae to persist may have important 
ramifications for temperate reef communities because macroalgae harbor amphipods and other crustaceans that are a critical source of food for benthic fish (Laur \& Ebeling 1983, Holbrook \& Schmitt 1992).

The present study focuses on the behavioral mechanism underlying an associational refuge on temperate reefs involving the small colonial anemone Corynactis californica (hereafter Corynactis). This species has particularly powerful nematocysts (Skaer \& Picken 1965), aggressively uses its mesenterial filaments to kill neighboring sessile organisms (Chadwick 1987), and can impede movement of sea stars (Patton et al. 1991). The following questions were addressed in the present study: (1) Does the distribution of Corynactis explain significant variation in the abundance of sea urchins on reefs where they co-occur?; (2) Do sea urchins avoid contact with Corynactis and does their behavioral response vary among species of urchins? (3) Can Corynactis facilitate the recruitment of benthic macroalgae within urchin barrens? I hypothesized that if sea urchins are impeded by the stinging tentacles of Corynactis, then sea urchins should be less common in areas where Corynactis is dense, exhibit signs of stress when in contact with Corynactis, and avoid contact with polyps. If the above hypotheses are true, then Corynactis could facilitate recruitment of macroalgae amidst high densities of sea urchins on barren reefs.

\section{MATERIALS AND METHODS}

Distribution of macroalgae among Corynactis. Carpinteria Reef (Santa Barbara Channel, CA, USA; $\left.34^{\circ} 23^{\prime} \mathrm{N}, 119^{\circ} 32^{\prime} \mathrm{W}\right)$ is a shallow $(<12 \mathrm{~m})$ rocky reef heavily grazed by red (Strongylocentrotus franciscanus) and purple urchins (S. purpuratus). The reef was surveyed to determine whether macroalgae were more abundant among Corynactis colonies than adjacent areas without Corynactis. Nine Corynactis patches (all oriented horizontally) were surveyed in July 2005, each between 20 and $50 \mathrm{~cm}$ in diameter at a water depth of $7 \mathrm{~m}$. An $18 \times 9 \mathrm{~cm}$ frame was placed in the center and then outside the perimeter of each Corynactis patch. The area within each frame was photographed and the percent cover of benthic taxa was estimated by superimposing a grid of at least 30 points over each photograph and recording the primary space holder.

Spatial distribution of sea urchins and Corynactis. To determine whether sea urchins were less common in areas where Corynactis is dense, the distribution of Corynactis was compared with that of sea urchins at 3 spatial scales: (1) in $400 \mathrm{~m}^{2}$ areas among reefs separated by 10 to $50 \mathrm{~km}$; (2) in $0.25 \mathrm{~m}^{2}$ areas within a single reef; and (3) within the area occupied by an individual urchin. Data obtained from the Channel Islands
National Park Service's Kelp Forest Monitoring Program were used to examine the distributions of Corynactis and sea urchins at the among-reef scale, which included 15 rocky reefs on 5 islands (Santa Barbara, Anacapa, Santa Cruz, Santa Rosa, and San Miguel). Data used for this analysis were from 2001, the year that had the largest range in the percent cover of Corynactis (Kushner et al. 2004), and hence the greatest chance of detecting an antagonistic relationship between Corynactis and sea urchins. On each reef, densities of red and purple urchins were counted in twenty $2 \mathrm{~m}^{2}$ quadrats placed at random intervals along a $100 \times$ $4 \mathrm{~m}$ transect at depths ranging from 7 to $15 \mathrm{~m}$. The percent of reef surface covered by Corynactis was estimated by identifying the primary substrate holder and any overlapping taxa at 40 randomly spaced points within a $0.5 \times 3 \mathrm{~m}$ area at 25 random locations along the transect (for details, see Davis 1988). Simple linear regressions were used to determine the extent to which the cover of Corynactis predicted the density of purple and red urchins.

The percent cover of Corynactis and density of urchins were surveyed in $0.25 \mathrm{~m}^{2}$ patches on horizontally oriented bedrock at Naples Reef, an isolated outcrop located $2 \mathrm{~km}$ offshore and $23 \mathrm{~km}$ west of Santa Barbara, CA $\left(34^{\circ} 25^{\prime} \mathrm{N}, 119^{\circ} 57^{\prime} \mathrm{W}\right.$; Ebeling et al. 1985). The density of red and purple urchins and cover of Corynactis on Naples Reef was measured in sixty-nine $50 \times 50 \mathrm{~cm}$ quadrats placed approximately $2 \mathrm{~m}$ apart at a water depth of 9 to $12 \mathrm{~m}$ in June 2003. Quadrats were gridded with monofilament line and the primary space holder was identified at 81 uniformly spaced points within each quadrat. The extent to which cover of Corynactis predicted the density of purple and red urchins was assessed using simple linear regression.

To examine the distribution of Corynactis at the scale of individual urchins, the number of Corynactis polyps touching each urchin was compared with what would be expected if urchins were randomly distributed over the same area. Two non-adjacent and horizontally oriented areas on Naples Reef $(2 \times 10 \mathrm{~m})$ were surveyed in February 2002 ( $N=717$ purple urchins, 39 red urchins for both areas combined). Kelp (e.g. Macrocystis pyrifera and Pterygophora californica) was rare and most urchins were considered to be foraging, based on being in open, exposed microhabitat. For each urchin in an exposed microhabitat, the test diameter was recorded with a ruler and also the number of Corynactis polyps that the urchin touched. To test whether urchins were touching fewer polyps than expected, a purple urchin ( $5 \mathrm{~cm}$ test diameter; $\mathrm{N}=692$ ) and a red urchin $(9 \mathrm{~cm} ; \mathrm{N}=279)$ were placed on the reef and the number of Corynactis polyps in contact with the urchin were counted. A chi-square test was used to compare the number of Corynactis polyps in contact with ran- 
domly placed purple and red urchins to the actual number of polyps observed touching those that were naturally distributed.

Effect of Corynactis on urchin behavior. To test whether urchins avoided contact with Corynactis, I placed red and purple urchins on substrata with or without Corynactis and recorded movement and tube feet (podia) behavior. Experiments were done in flowthrough seawater tanks $(56 \mathrm{~cm} \times 2.9 \mathrm{~m})$ at the University of California Santa Barbara Marine Science Institute (UCSB-MSI) in July 2002. Purple and red urchins were collected from pier pilings adjacent to UCSB-MSI. Mean test diameter $( \pm 1 \mathrm{SE})$ was $53 \pm 3$ and $53 \pm 4 \mathrm{~mm}$ for purple and red urchins, respectively. Corynactis colonies were collected from an offshore oil production platform in the Santa Barbara Channel (Platform Gina, $34^{\circ} 07^{\prime} \mathrm{N}, 119^{\circ} 16^{\prime} \mathrm{W}$ ), where they naturally occur on the shells of rock scallops Crassedoma giganteum and mussels Mytilus californianus. Scallop and mussel shells were used as Corynactis substrate in lieu of natural rock because of the inherent difficulties in collecting and manipulating colonies of Corynactis on rocky substrata. Each individual urchin was placed once on a scallop shell $(\sim 15 \mathrm{~cm}$ diameter $)$ with $100 \%$ cover of Corynactis and once on a bare scallop shell, alternating the order of treatments after each set $(\mathrm{N}=15$ and 21 individuals for purple and red urchins, respectively). Different shells were used for each replicate trial to minimize the effects of repeated disturbance to any one Corynactis colony. Locomotive behavior in urchins was assessed using 2 methods: (1) the time elapsed until an urchin moved completely off a shell was recorded, with trials otherwise terminated after $5 \mathrm{~min}$, and (2) the number of podia touching the shell. The number of podia was counted using photographs taken through a side of the clear, plexiglass tank approximately $30 \mathrm{~s}$ after an urchin was placed on a shell.

The number of red and purple urchins to move off shells with or without Corynactis within 5 min was compared using a chi-square test. The time elapsed for red urchins to move off shells with or without Corynactis was compared using a paired $t$-test. Only red urchins were compared in this manner since few purple urchins moved off shells covered by Corynactis. The effect of Coynactis on the number of podia used in locomotion (i.e. attached to the substrate) was evaluated for each species of urchin with a paired $t$-test. The number of podia was square root transformed to meet the assumption of homoscedasticity. Since the effect of Corynactis varied between the 2 species of urchins, and it might have been influenced by morphological differences, the length of the longest spine for purple and red urchins was compared using a 2-tailed Student's $t$-test.

Laboratory trials using barriers of Corynactis to separate red and purple urchins from kelp were per- formed to determine whether Corynactis was capable of impeding foraging urchins. Both red and purple urchins were collected from pier pilings adjacent to UCSB-MSI and starved for 2 wk in flow-through seawater tanks at UCSB-MSI in December 2003. Mussel shells, covered with Corynactis, were manipulated to create 3 levels of cover: 0, 30, and $100 \%$. A flowthrough seawater tank was subdivided into six $22 \times$ $76 \mathrm{~cm}$ channels, with 2 channels allocated to each treatment. Water passed through each channel's partitions. Within each channel, a barrier of mussel shells of one level of cover was constructed in the center with one starved urchin on one side and a $5 \mathrm{~g}$ square of fresh giant kelp Macrocystis pyrifera on the other. A total of 30 red urchins was used once for each treatment and their movements were monitored for $90 \mathrm{~min}$. The same process was repeated for purple urchins, except urchins were randomly chosen from a pool of approximately 60 individuals, so that 33,44, and 55 individual trials were run for the 0,30 , and $100 \%$ treatments, respectively. Treatments were rotated among the 6 channels to control for bias. The number of individuals that crossed the mussel shell barrier in the $0 \%$ cover treatment was used to establish the a priori expected ratios of successfully crossing the barrier. The number of purple and red urchins to cross the 30 and $100 \%$ cover treatments was analyzed using chi-square goodness-of-fit tests with the Bonferroni technique of Byers \& Steinhorst (1984).

Facilitation of algal colonization by Corynactis. I transplanted Corynactis to a reef heavily grazed by urchins to test whether Corynactis facilitates algal recruitment. Scallop shells covered with Corynactis were used as substrate in lieu of natural rock to facilitate the manipulation of Corynactis. The benthic communities that develop on shells are similar to those that develop on natural rock (Levenbach in press b). A $170 \mathrm{~cm}^{2}$ area was cleared in the center of each shell to permit algae to settle. The remaining Corynactis on each shell was either completely removed ('no barrier', $N=12$ ), completely removed from one side ('half barrier', $\mathrm{N}=14$ ), or left intact ('full barrier', $N=15$ ). Thus, the area that was cleared for settlement on full barrier shells was surrounded by a ring of Corynactis that was approximately $2.5 \mathrm{~cm}$ wide. Shells were transplanted to Coal Oil Point $\left(34^{\circ} 23^{\prime} \mathrm{N}, 119^{\circ} 52^{\prime} \mathrm{W}\right)$, an urchin barren reef $13 \mathrm{~km}$ west of Santa Barbara, in September 2003. Shells were attached to $20 \times 20 \mathrm{~cm}$ PVC plates that were bolted into the reef and spaced approximately $1 \mathrm{~m}$ apart at a depth of $8 \mathrm{~m}$. Both species of urchins were counted in $0.25 \times 0.25 \mathrm{~m}$ quadrats haphazardly placed within the vicinity of transplanted shells during October $(\mathrm{N}=11)$ and November $2003(\mathrm{~N}=14)$. Throughout the experiment, the surrounding rock substrate was dominated by encrusting coralline algae 
and bare space was abundant. Photographs of the shells were taken after $10 \mathrm{wk}$ and a grid of at least 25 points was superimposed on each photograph and the primary space holder under each point was recorded. The effect of a Corynactis barrier on the proportion of surface area covered by algae was evaluated with a 1-way fixed factor ANOVA and differences among the 3 levels of barrier were assessed using a post-hoc Tukey HSD test. The proportion of algal cover was arcsine square root transformed to meet the assumption of homoscedasticity.

\section{RESULTS}

Within heavily grazed areas of Carpinteria Reef, macroalgae was more abundant within Corynactis colonies. The mean $( \pm \mathrm{SE})$ cover of Corynactis within patches was $18 \pm 5 \%$. Turf-forming algae (Polyneura latissima, Pterosiphonia sp., and Weeksia spp.) covered roughly one-third of the available surface area within Corynactis patches, and only $7 \%$ immediately outside of Corynactis patches (Fig. 1). Biotic structure was noticeably absent outside of Corynactis patches, which were dominated by encrusting coralline algae and bare space.

The percent cover of Corynactis on the 15 reefs at the Santa Barbara Channel Islands varied between 0 and $25 \%$. Densities of purple urchins ranged between 0 and 103 ind. $\mathrm{m}^{-2}$, and red urchins between 3 and 13 ind. $\mathrm{m}^{-2}$. There was no relationship between the cover of Corynactis and the density of purple urchins

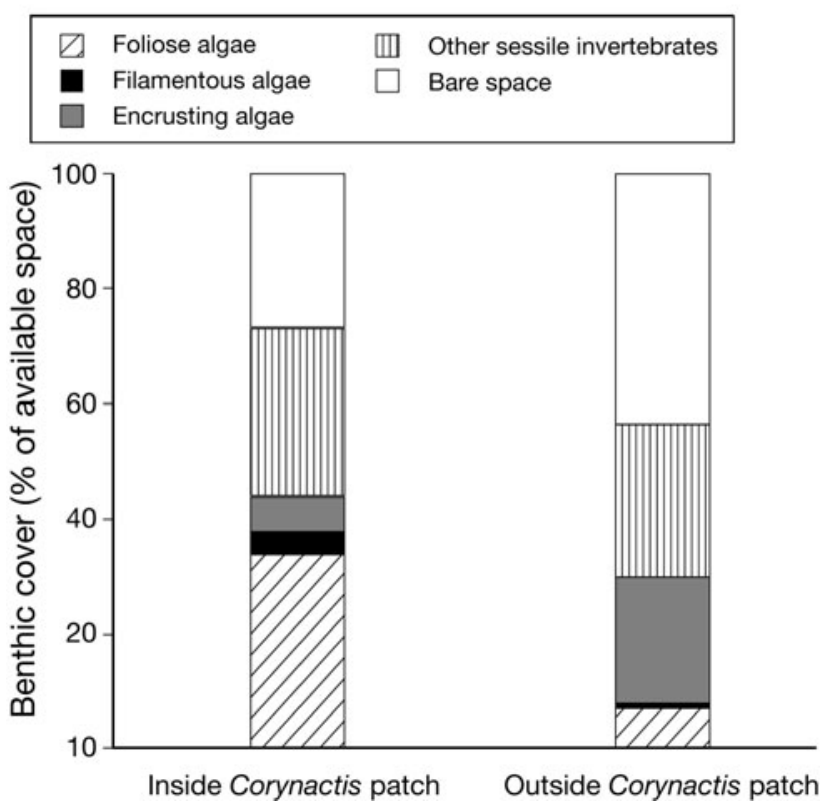

Fig. 1. Corynactis californica. Benthic cover within and outside of patches $(\mathrm{N}=9)$ on Carpinteria Reef. Cover was grouped into 5 categories $\left(r^{2}<0.01, d f=14, p=0.91\right)$. Red urchins were positively correlated with Corynactis $\left(\mathrm{r}^{2}=0.36, \mathrm{df}=14, \mathrm{p}=0.02\right)$ (Fig. 2), but this pattern was not significant when the reef with the highest cover of Corynactis was removed from the analysis $\left(\mathrm{r}^{2}<0.01\right.$, $\left.\mathrm{df}=14, \mathrm{p}=0.91\right)$. There was no relationship between the density of both urchin species combined and the cover of Corynactis $\left(\mathrm{r}^{2}<\right.$ 0.01 , df $=14, p=0.93$ ). Depth effects were not apparent, as the densities of urchins and Corynactis were uncorrelated with depth.

At the spatial scale of $0.25 \mathrm{~m}^{2}$ at Naples Reef, between 0 and $36 \%$ of plot surface area was covered by Corynactis. Density of purple urchins ranged between 0 and 20 ind. $0.25 \mathrm{~m}^{-2}$, and red urchins between 0 and 2 ind. $0.25 \mathrm{~m}^{-2}$. There was no relationship between the cover of Corynactis and purple $\left(\mathrm{r}^{2}=0.00, \mathrm{df}=67, \mathrm{p}=\right.$ 0.90) or red urchins $\left(\mathrm{r}^{2}=0.00, \mathrm{df}=67, \mathrm{p}=0.77\right)$.

At the smallest spatial scale both purple urchins $\left(\chi^{2}=\right.$ 210.2, df $=15, \mathrm{p}<0.001$ ) (Fig. 3a) and red urchins $\left(\chi^{2}=\right.$ 231.1, df $=10, \mathrm{p}<0.001$ ) (Fig. 3b) avoided contact with Corynactis as they touched significantly fewer polyps than would be expected based on a random distribution. Over $50 \%$ of purple urchins sampled were in contact with 0 or 1 Corynactis polyp compared to an expected value of about $18 \%$ if purple urchins were distributed randomly. By comparison, approximately $30 \%$ of the red urchins sampled were in contact with 0 or 1 Corynactis polyp compared to an expected value of $8 \%$. The mean test diameters were $4.9 \pm 0.1$ and $9.7 \pm 0.6 \mathrm{~cm}$ for purple and red urchins, respectively.

Laboratory experiments in which urchins were placed on shells with Corynactis revealed that both purple and red urchins were impeded by Corynactis, although the effect of Corynactis was greater on purple urchins (Fig. 4). While all the purple urchins moved off control shells lacking Corynactis, only 1 individual moved off the Corynactis treatment $\left(\chi^{2}=34.11\right.$, df $=29$, $\mathrm{p}<0.001)$. Many of the purple urchins placed on Cory-

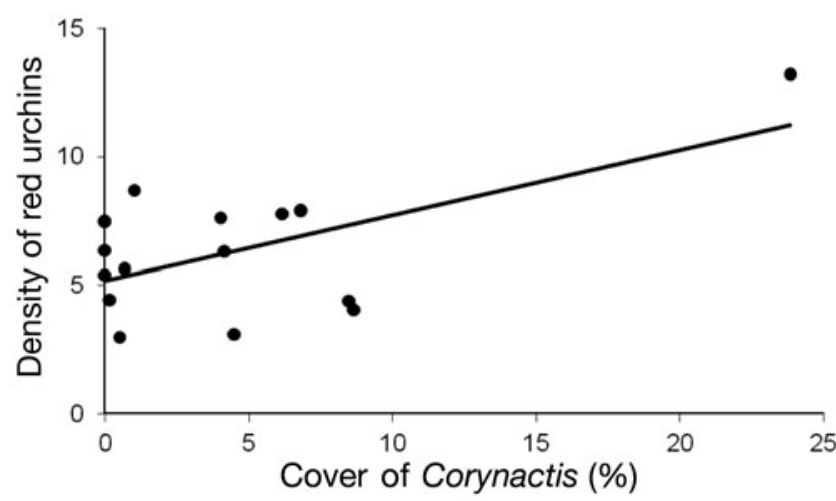

Fig. 2. Strongylocentrotus franciscanus. Density of red sea urchins as a function of the percent cover of Corynactis californica on 15 rocky reefs from 5 islands in the Santa Barbara Channel $\left(\mathrm{r}^{2}=0.36, \mathrm{df}=14, \mathrm{p}=0.02\right)$ 

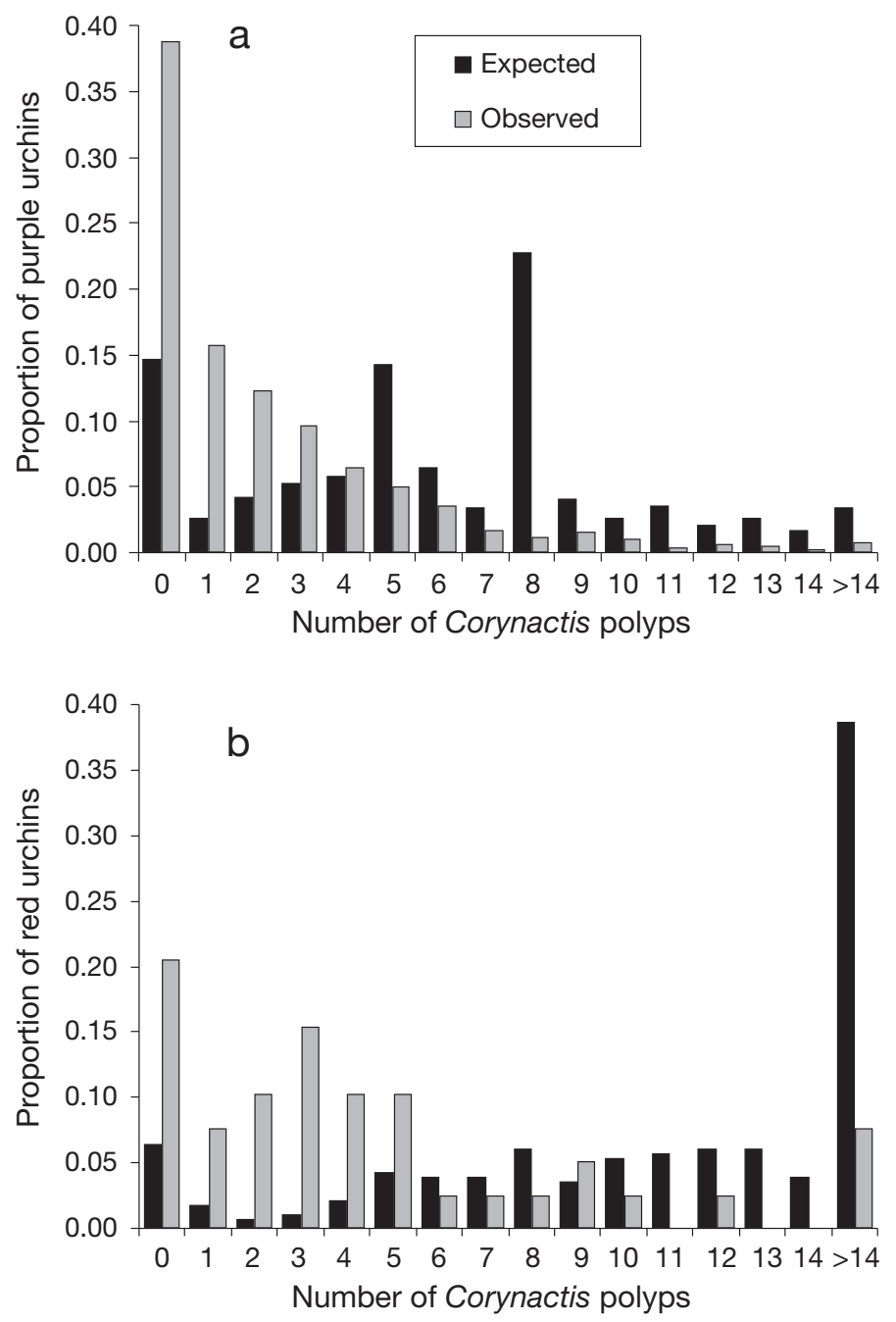

Fig. 3. Corynactis californica. Expected and observed numbers of polyps in contact with (a) purple urchins $(\sim 5 \mathrm{~cm}$ test diameter; $\left.\chi^{2}=210.2, \mathrm{df}=15, \mathrm{p}<0.001\right)$ and (b) red urchins $\left(\sim 9 \mathrm{~cm}\right.$ test diameter; $\left.\chi^{2}=231.1, \mathrm{df}=10, \mathrm{p}<0.001\right)$ on Naples Reef, Santa Barbara Channel

nactis began to spawn and defecate, indicating that they were stressed. Nearly all red urchins moved off both Corynactis and bare shells within $5 \min \left(\chi^{2}=0.37\right.$, $\mathrm{df}=41, \mathrm{p}=0.55)$ (Fig. 4), but the mean ( $\pm 1 \mathrm{SE})$ time to move off shells covered with Corynactis was significantly longer ( $295 \pm 12$ s) than shells lacking Corynactis $(157 \pm 12 \mathrm{~s}$; $t$-ratio $=8.27, \mathrm{df}=14, \mathrm{p}<0.0001)$.

Both red and purple urchins retracted their podia upon contact with Corynactis and consequently used only about one-fifth the number of podia when moving on shells with Corynactis compared to shells lacking Corynactis (purple: $t$-ratio $=11.97, \mathrm{df}=28, \mathrm{p}<0.001$; red: $t$-ratio $=14.34, \mathrm{df}=40, \mathrm{p}<0.001$ ) (Fig. 5). With their podia retracted, purple urchins moved very little after being placed on Corynactis. In contrast, red urchins continued to move over Corynactis, albeit at a

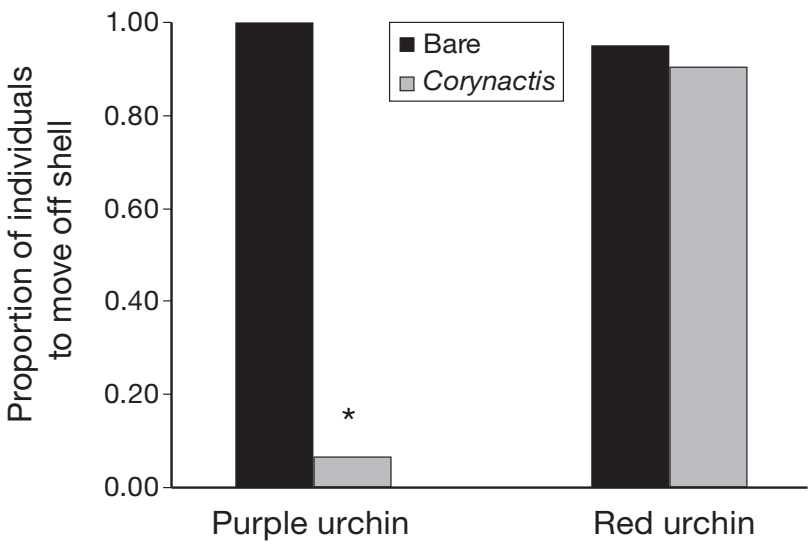

Fig. 4. Strongylocentrotus purpuratus and S. franciscanus. Laboratory trials of the proportion of purple urchins $(\mathrm{N}=15)$ and red urchins $(\mathrm{N}=21)$ to move off of shells either covered with Corynactis californica or bare. *: column is significantly different from its respective control $(\mathrm{p}<0.001)$ by a chi-square test

slower rate. Although the individuals used in the trials were similar in test diameter, the spines of red urchins were more than 3 times longer than those of purple urchins (red: $30 \pm 2 \mathrm{~mm}_{\text {; }}$ purple: $10 \pm 1 \mathrm{~mm}$; $t$-ratio $=$ 10.01, $\mathrm{df}=23.4, \mathrm{p}<0.001$ ).

Laboratory experiments revealed that $70 \%$ of purple urchins moved across shells lacking Corynactis, while only $5 \%\left(\chi^{2}=85.4, \mathrm{df}=1, \mathrm{p}<0.001\right)$ and $9 \%\left(\chi^{2}=92.8\right.$, $\mathrm{df}=1, \mathrm{p}<0.001)$ of purple urchins crossed barriers with 30 and $100 \%$ cover of Corynactis, respectively (Fig. 6). Red urchins were not deterred from crossing the $30 \%$ cover treatment (Fig. 6), retracting their podia and using their spines to move across Corynactis $\left(\chi^{2}=\right.$ $2.75, \mathrm{df}=1, \mathrm{p}=0.10$ ), but only $13 \%$ crossed barriers completely covered with Corynactis $\left(\chi^{2}=21.2, \mathrm{df}=1\right.$, $\mathrm{p}<0.001)$.

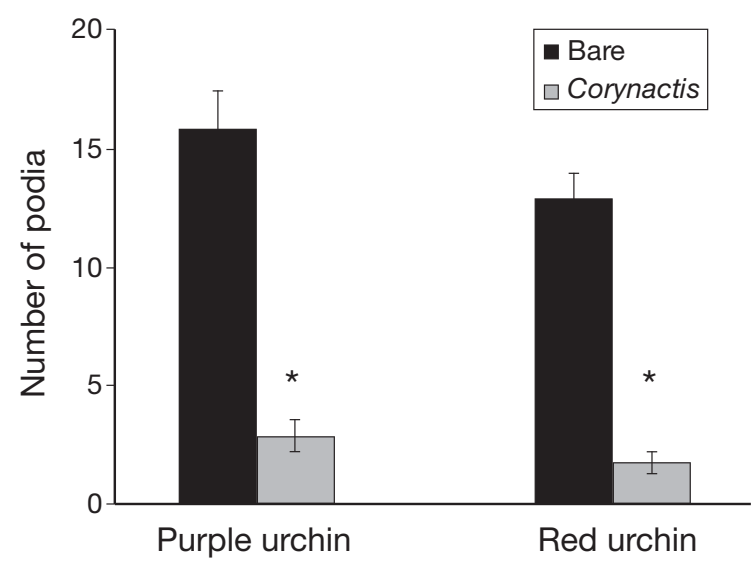

Fig. 5. Strongylocentrotus purpuratus and S. franciscanus. Laboratory trials of the number of podia (mean $\pm 1 \mathrm{SE}$ ) used in locomotion on bare shells and shells covered with Corynactis californica for both purple and red urchins. *: column is significantly different from its respective control (paired $t$-test, $\mathrm{p}<0.001)$ 
Sea urchins were abundant at Coal Oil Point during the time Corynactis colonies were transplanted to the reef. The mean $( \pm 1 \mathrm{SE})$ density of purple urchins was $3.0 \pm 1.1$ and $2.8 \pm 0.7$ ind. per $0.06 \mathrm{~m}^{2}$ in October and November, respectively. The mean $( \pm 1 \mathrm{SE})$ density of red urchins was $0.3 \pm 0.2$ ind. per $0.06 \mathrm{~m}^{2}$ in both months. Within $10 \mathrm{wk}$ of being transplanted, filamentous red algae (e.g. Ceramium sp.) recruited to shells with a complete barrier of Corynactis, while the shells without Corynactis remained largely bare (ANOVA, $F_{2,38}=15.33, p<0.001$ ) (Fig. 7). The area of shell covered with algae in the full barrier treatments was 4 times greater than that of the half barrier treatment and 25 times greater than that of the no barrier treatment. There were no other organisms occupying primary space on the shells other than filamentous algae.

\section{DISCUSSION}

Associational plant defenses have been defined to occur 'when a plant that is susceptible to herbivory gains protection when it is associated with another plant' (Pfister \& Hay 1988, p. 1). However, as noted by the example reported in the present study, this de-

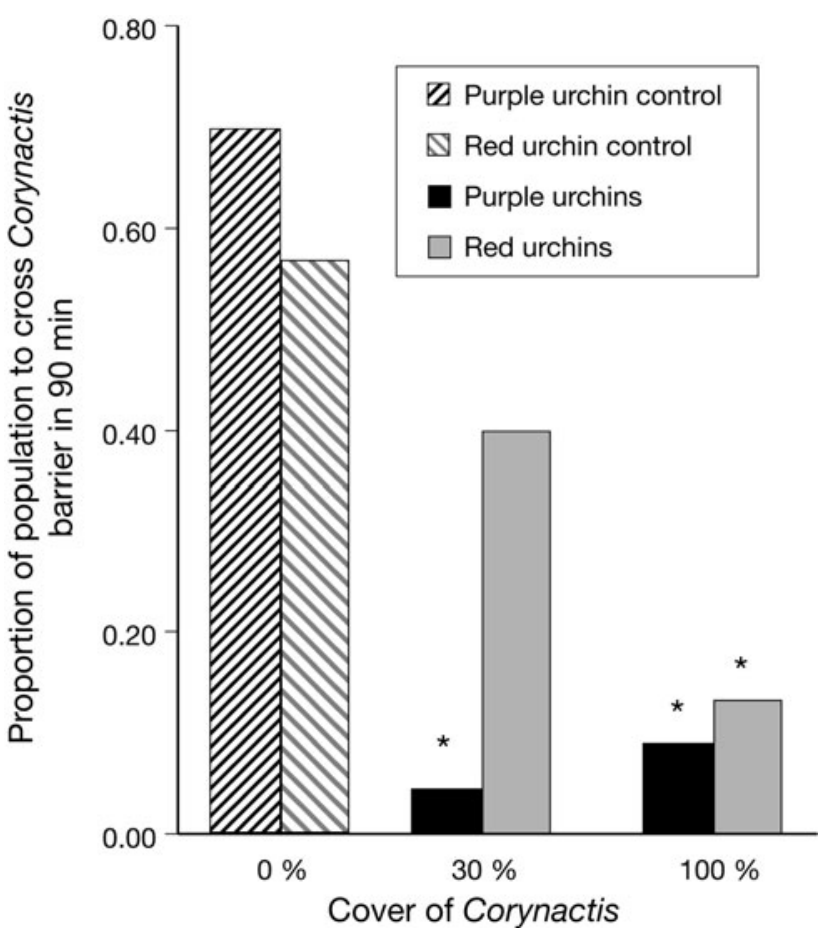

Fig. 6. Strongylocentrotus purpuratus and S. franciscanus. Laboratory trials of the proportion of purple urchins $(\mathrm{N}=33,44$, and 55 for 0,30 , and $100 \%$ cover treatments, respectively) and red urchins $(\mathrm{N}=30)$ that crossed a barrier with 0,30 , and $100 \%$ cover of Corynactis californica. *: column is significantly different from its respective control $(\mathrm{p}<0.001)$ by chi-square test with Bonferroni technique

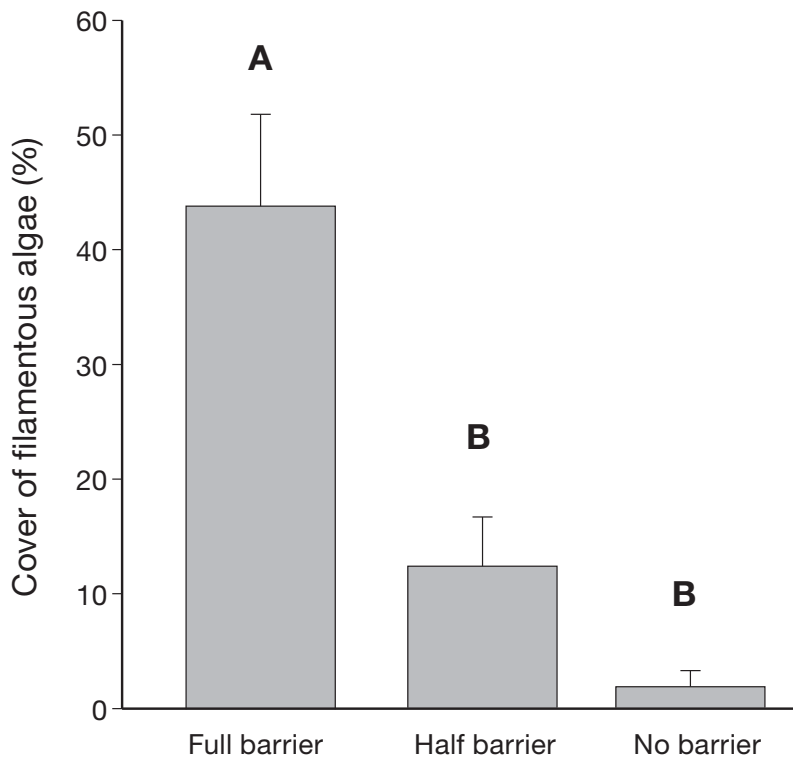

Fig. 7. Mean $( \pm 1 \mathrm{SE})$ algal cover in the focal area of shells transplanted to Coal Oil Point, Santa Barbara Channel after 10 wk. Shell perimeters were either completely covered with Corynactis californica (Full barrier, $\mathrm{N}=15$ ), half-covered (Half barrier, $\mathrm{N}=14$ ) or Corynactis was completely removed from shells (No barrier, $N=12$ ). Letters indicate significantly different groups $(\mathrm{p}<0.05)$ by Tukey-Kramer HSD

finition does not capture the entire range of interactions involving vulnerable primary producers and their benefactors. Animal-mediated associational defenses have been less frequently reported, perhaps because many of the examples of associational plant defenses come from terrestrial systems where most animals are vagile. Situations in which animals have been observed to benefit terrestrial plants are characterized as indirect positive effects (e.g. Ripple et al. 2001) or mutualisms (e.g. Heil et al. 2001). An important contributing factor towards the paucity of examples of animal-mediated associational plant defenses are the challenges in distinguishing associational defenses among the many variations of positive interactions that occur in ecological communities.

Marine systems ostensibly offer more opportunities for animal-mediated associational plant defenses, as many invertebrates have sessile adult life stages whose larvae settle alongside benthic macroalgae on hard substrata. The close proximity of macroalgae and sessile invertebrates leads to scenarios exemplified by the soft coral Sinularia sp., whose complex structure provides a temporary physical refuge for newly settled algal spores until algae develop chemical and structural defenses of their own (Kerr \& Paul 1995). Examples of chemical protection include the sea fan Gorgonia ventalina, which coats abrading algae with an extract that makes algae less palatable (Littler et al. 1987). Similarly, the stinging cells of the fire coral 
Millepora alcicornis deter herbivorous tropical reef fish from grazing neighboring macroalgae (Littler et al. 1987).

In the present study, Corynactis stung the tube feet (podia) of urchins and impeded their movement, thereby providing a possible mechanism that could facilitate macroalgal colonization and growth. The podia of sea urchins perform a variety of important functions besides locomotion, including adhesion, feeding, shading, sensing, and respiration, and many podia are specialized for one of these functions (Leddy \& Johnson 2000). Loss of even $10 \%$ of podia results in mortality of some species of urchins (Williamson et al. 2004). Both purple and red urchins quickly withdrew nearly all their podia when one foot came into contact with a Corynactis polyp. This contributed to the inability of purple urchins to move when on top of Corynactis, and significantly slowed movement in red urchins.

The consequence of the interspecific antagonism on Carpinteria Reef, where grazing purple urchins created vast barren areas, was that turf algae persisted where mixed among colonies of Corynactis. Like Carpinteria Reef, many reefs in the Santa Barbara Channel are dominated by purple urchins (Kushner et al. 2004). However, it is unclear whether the associational refuge described here would be equally probable on reefs dominated by longer-spined red urchins, or where grazing intensity is extremely high. Although red urchins can conceivably crawl over Corynactis and graze on associated macroalgae, the benefit of food would have to be greater than the costs of contact with Corynactis. Levenbach (in press b) found that Corynactis protected turf algae under intermediate levels of grazing by purple urchins, but urchins were undeterred at high densities.

The negative effect of Corynactis on sea urchins was not evident at spatial scales of 400 and $0.25 \mathrm{~m}^{2}$, as there was not an inverse relationship between the distribution of Corynactis and abundance of urchins. One explanation is that the negative effect of Corynactis on urchins is offset by sea urchin grazing, which has a positive indirect effect on Corynactis by consuming macroalgal competitors. Foliose algae abrade the tentacles of sessile cnidarians and are likely to interfere with feeding (Coyer et al. 1993), leading to sharp declines in body size (Levenbach in press a). Behrens \& Lafferty (2004) found the abundance of Corynactis to be positively correlated with the presence of sea urchin barrens where competition from foliose algae is low. Conversely, Corynactis may have a stronger positive effect on macroalgal abundance on barren reefs where urchins are more likely to encounter polyps. Lees (1970) found that, on forested reefs, only $3 \%$ of a population of tagged purple urchins moved farther than $1.2 \mathrm{~m}$ in a $12 \mathrm{mo}$ period, compared to $37 \%$ of the urchin population on a barren reef.
The associational refuge reported here may have important ramifications for kelp forest ecology, as sea urchins are a dominant herbivore on temperate reefs and urchin barrens are common phenomena worldwide (Tegner \& Dayton 2000). Along the California coast, sea urchin fronts have been observed to rapidly consume all extant foliose algae, leaving substrata dominated by crustose algae and depauperate species diversity (Ebeling et al. 1985, Watanabe \& Harrold 1991). Because many small crustaceans aggregate in turf algae, refuge provided to turf algae by Corynactis not only serves to enhance algal diversity but may also have important consequences for secondary production and benthic fishes (Laur \& Ebeling 1983, Holbrook \& Schmitt 1992). In related studies, benthic macroalgae recruited among Corynactis colonies that were transplanted within urchin barrens and the algae and small crustaceans persisted for over $2 \mathrm{yr}$ while the surrounding area continued to be devoid of foliose macroalgae (Levenbach in press a).

The taxonomic group of corallimorpharia, of which Corynactis californica is a member, is found worldwide and may have positive effects on other species. Sea stars Pisaster spp., like their echinoderm counterparts in this study, avoid contact with Corynactis tentacles. On pier pilings in the Santa Barbara Channel, mussels Mytilus spp., rock scallops Crassedoma giganteum, and clams Chama arcana were more abundant among Corynactis colonies (Landenberger 1967, Patton et al. 1991). In laboratory trials, mussels were not eaten when their shells were fouled with Corynactis (Landenberger 1967), and predation by Pisaster on clams was slower when the clams were mixed among Corynactis polyps (Patton et al. 1991). The temperate congener, Corynactis viridis, also has powerful nematocysts (Skaer \& Picken 1965, Muntz et al. 1972), and a related tropical corallimorpharian, Rhodactis rhodostoma, uses its tentacles to strongly compete for space (Langmead \& Chadwick-Furman 1999, Kuguru et al. 2004). Studying these and other marine invertebrates may help to broaden our understanding of associational refuges and their role in ecological communities.

Acknowledgements. The field work was aided by Q. Do, C. Kane, M. Kay, A. Parsons-Field, B. Pitterle, C. Simpson, and T. Welche. M. Leibold, S. London, and C. Newmeyer assisted in the laboratory. This research benefited from conversations with A. Brooks, D. Greenberg, H. Lenihan, S. Holbrook, A. Rassweiler, W. Rice, D. Reed, and R. Schmitt. D. Kushner and Channel Islands National Park graciously provided the use of monitoring data. Special thanks go to the generous financial and logistical support from the Santa Barbara Coastal LTER (NSF grant no. OCE-9982105), and the Nuevo Energy Company for access to oil platforms. This research was supported by graduate student fellowships from the University of California Toxic Substances and Teaching Program, the University of California Marine Council's Coastal 
Environmental Quality Initiative, the Nancy Brown Environmental Graduate Dissertation Fellowship, and a Regent's Fellowship from the University of California Santa Barbara.

\section{LITERATURE CITED}

Atsatt PR, O'Dowd DJ (1976) Plant defense guilds. Science 193:24-29

Baraza E, Zamora R, Hodar JA (2006) Conditional outcomes in plant-herbivore interactions: neighbors matter. Oikos 113: 148-156

Behrens MD, Lafferty KD (2004) Effects of marine reserves and urchin disease on southern California rocky reef communities. Mar Ecol Prog Ser 279:129-139

Byers CR, Steinhorst RK (1984) Clarification of a technique for analysis of utilization availability data. J Wildl Manag 48: 1050-1053

Callaway RM, Kikvidze Z, Kikodze D (2000) Facilitation by unpalatable weeds may conserve plant diversity in overgrazed meadows in the Caucasus Mountains. Oikos 89: 275-282

> Chadwick N (1987) Interspecific aggressive behavior of the corallimorpharian Corynactis californica (Cnidaria: Anthozoa): effects on sympatric corals and sea anemones. Biol Bull 173:110-125

Coyer JA, Ambrose RF, Engle JM, Carroll JC (1993) Interactions between corals and algae on a temperate zone rocky reef: mediation by sea urchins. J Exp Mar Biol Ecol 167: 21-37

Davis GE (1988) Kelp forest monitoring handbook for Channel Islands National Park, California. Channel Islands National Park Natural Science Reports, Ventura, CA

Ebeling AW, Laur DR, Rowley RJ (1985) Severe storm disturbances and reversal of community structure in a southern California kelp forest. Mar Biol 84:287-294

> Gagnon P, Himmelman JH, Johnson LE (2003) Algal colonization in urchin barrens: defense by association during recruitment of the brown alga Agarum cribrosum. J Exp Mar Biol Ecol 290:179-196

Hamback PA, Agren J, Ericson L (2000) Associational resistance: insect damage to purple loosestrife reduced in thickets of sweet gale. Ecology 81:1784-1794

> Harrold C, Reed DC (1985) Food availability, sea urchin grazing, and kelp forest community structure. Ecology 66: 1160-1169

Hay ME (1986) Associational plant defenses and the maintenance of species diversity: turning competitors into accomplices. Am Nat 128:617-641

Heil M, Fiala B, Maschwitz U, Linsenmair KE (2001) On benefits of indirect defense: short and long term studies of antiherbivore protection via mutualistic ants. Oecologia 126: 395-403

Holbrook SJ, Schmitt RJ (1992) Causes and consequences of dietary specialization in surfperches: patch choice and intraspecific competition. Ecology 73:402-412

Kerr JNQ, Paul VJ (1995) Animal-plant defense association: the soft coral Sinularia sp. (Cnidaria, Alcyonacea) protects Halimeda spp. from herbivory. J Exp Mar Biol Ecol 186: 183-205

Kuguru BL, Mgaya YD, Ohman MC, Wagner GM (2004) The reef environment and competitive success in the Corallimorpharia. Mar Biol 145:875-884

Kushner DJ, Lerma D, Ugoretz K (2004) Kelp Forest Monitoring, 2001 Annual Report. Technical Report-CHIS-0302. Channel Islands National Park, Ventura, CA

Landenberger DE (1967) A study of predation and predatory behavior in the Pacific starfish, Pisaster. PhD dissertation,
University of California, Santa Barbara, CA

> Langmead O, Chadwick-Furman NE (1999) Marginal tentacles of the corallimorpharian Rhodactis rhodostoma. 1. Role in competition for space. Mar Biol 134:479-489

> Laur DR, Ebeling AW (1983) Predator-prey relationships in surfperches. Environ Biol Fishes 8:217-229

Lawrence JM (1975) On the relationships between marine plants and sea urchins. Oceanogr Mar Biol Annu Rev 13: $213-286$

Leddy HA, Johnson AS (2000) Walking versus breathing: mechanical differentiation of sea urchin podia corresponds to functional specialization. Biol Bull 198:88-93

Lees DC (1970) The relationship between movement and available food in the sea urchins Strongylocentrotus franciscanus and Strongylocentrotus purpuratus. MS dissertation, San Diego State College, San Diego, CA

Levenbach $\mathrm{S}$ (in press a) Community-wide ramifications of an associational refuge on shallow rocky reefs. Ecology

Levenbach S (in press b) Grazing intensity influences the strength of an associational refuge on temperate reefs. Oecologia

> Littler MM, Littler DS, Taylor PR (1987) Animal plant defense associations: effects on the distribution and abundance of tropical reef macrophytes. J Exp Mar Biol Ecol 105: $107-121$

McClintock JB, Baker BJ (2001) Marine chemical ecology. CRC Press, Boca Raton, FL

Milchunas DG, Noy-Meir I (2002) Grazing refuges, external avoidance of herbivory and plant diversity. Oikos 99: 113-130

Muntz L, Ebling FJ, Norton TA, Kitching JA (1972) Ecology of Lough Ine.18. Factors controlling distribution of Corynactis viridis Allman. J Anim Ecol 14:735-750

Patton ML, Brown ST, Harman RF, Grove RS (1991) Effect of the anemone Corynactis californica on subtidal predation by sea stars in the southern California bight. Bull Mar Sci 48:623-634

Paul VJ, Cruz-Rivera E, Thacker RW (2001) Chemical mediation of macroalgal-herbivore interactions: ecological and evolutionary perspectives. In: McClintock JB, Baker BJ (eds) Marine chemical ecology. CRC Press, Boca Raton, FL, p 227-266

> Pfister CA, Hay ME (1988) Associational plant refuges: convergent patterns in marine and terrestrial communities result from differing mechanisms. Oecologia 77:118-129

> Rebollo S, Milchunas DG, Noy-Meir I, Chapman PL (2002) The role of a spiny plant refuge in structuring grazed shortgrass steppe plant communities. Oikos 98:53-64

Ripple WJ, Larsen EJ, Renkin RS, Smith DW (2001) Trophic cascades among wolves, elk and aspen on Yellowstone National Park's northern range. Biol Conserv 102:227-234

> Rosenthal JP, Kotanen PM (1994) Terrestrial plant tolerance to herbivory. Trends Ecol Evol 9:145-148

Skaer RJ, Picken ER (1965) The structure of the nematocyst thread and the geometry of discharge in Corynactis viridis Allman. Phil Trans R Soc Lond B 250:131-164

Stachowicz JJ (2001) Mutualisms, facilitation, and the structure of ecological communities. Bioscience 51:235-246

Tegner MJ, Dayton PK (2000) Ecosystem effects of fishing in kelp forest communities. ICES J Mar Sci 57:579-589

Watanabe JM, Harrold C (1991) Destructive grazing by sea urchins Strongylocentrotus spp. in a central California kelp forest: potential roles of recruitment, depth, and predation. Mar Ecol Prog Ser 71:125-141

> Williamson JE, Carson DG, De Nys R, Steinberg PD (2004) Demographic consequences of an ontogenetic shift by a sea urchin in response to host plant chemistry. Ecology 85:1355-1371 